\title{
Organizational Time and Social Conflict
}

\author{
Louis Hicks* \\ St. Mary's College of Maryland
}

*Send correspondence to Prof. Louis Hicks, Department of Sociology, St. Mary’s

College of Maryland, St. Mary’s City, MD 20686, 240-895-4915, lehicks@smcm.edu 


\title{
Organizational Time and Social Conflict
}

\begin{abstract}
Modeled after Donald Black's Moral Time, a movement of organizational time is any change in organizational space. Organization takes three forms: inclusion, regulation, and distinction. Overorganization is an increase in an organization's size (overinclusion), regulatory activity (overregulation), or subculture (overdistinction). Underorganization is a contraction in size (underinclusion), regulatory activity (underregulation), or subculture (underdistinction). Numerous examples show how conflict is a direct function of the movement of organizational time.
\end{abstract}




\section{Organizational Time and Social Conflict}

\section{INTRODUCTION}

In The Behavior of Law ([1976] 2010) Donald Black explained legal variation using a social space of five dimensions: horizontal; vertical; corporate; cultural; and normative. In its original form, Black's theory is largely a theory of legal cases. The locations in social space were those of the legal actors in a particular case (witnesses, judges, litigants, perpetrators, and so forth). In subsequent work, Black (1998) extended the paradigm beyond the explanation of patterns among legal cases to conflict management more generally while still retaining the basic outline of his social space. Other scholars have extended the pure sociology paradigm to homicide (Cooney 2009), welfare (Michalski 2003), genocide (Campbell 2009), suicide (Manning 2012), suburbia (Baumgartner 1991) and other areas of social life.

In Black's Moral Time $(2011,4)$, the "fundamental cause of conflict is the movement of social time." A movement of social time is a fluctuation inside a social space that has three main dimensions: relational, vertical, and cultural. The relational dimension is horizontal and may be described as the extent to which actors participate in each other's lives. The vertical dimension is the unequal distribution of any form of status in relationships, that is, inequality. The cultural 
dimension is the symbolic or expressive dimension of social life. Fluctuation in each of these dimensions is called social time. Thus, relational time is change in the extent to which actors' participate in each others' lives. Vertical time is change in stratification. Cultural time is change in the expressive dimension of social life. Using only these three dimensions, Black explains a wide range of instances of moral conflict across many societies and centuries.

The movements of social time go on in the three-dimensional space present in any social relationship. The movements of social time can also occur within a formal organization. Inside a formal organization can be found vertical, relational, and cultural dimensions whose meaning is partly particular to that one organization. For example, an officer's rank in the U.S. Marine Corps is location on the vertical dimension that is specific to the organization. This rank has profound meaning within the organization but might mean little outside it. A formal organization, then, is a three-dimensional subspace embedded in the much larger mosaic of social space of the social universe as a whole.

An entire organization - a subspace - can also move inside the 3-D social space of the social universe. An organization could become more prestigious, or it could interact more with more people in the world, or its vocabulary could spread 
beyond its own discourse into the wider world. Conversely, it could shrink away to nothing, eventually popping out of existence.

Organizational space is a formal organization's special manifestation of the three dimensions of social space. Fluctuation inside that space and between that space and the larger social world is organizational time. Like the other three kinds of social time, organizational time explains social conflict. Starting and expanding organizations along with shrinking and decaying organizations are causes of some of the most consequential social conflicts ever seen. When corporations go bankrupt and are dissolved by a court - a large movement of organizational time retirees sometimes lose their pensions. When John D. Rockefeller was assembling the Standard Oil Company, Inc., tremendous social conflict ensued. When the U.S. Supreme Court ruled in 1911 that Standard Oil was a monopoly and had to be dismantled, yet more social conflict followed. The legal recognition of corporations as people was another large movement of social time that caused social conflict.

This article describes organizational time in terms of three primordial features of all organizations: inclusion, regulation, and distinctiveness. These dimensions correspond to the larger dimensions of the social world: relational, vertical, and cultural. At any point in time for a particular organization, some people and things 
are included in the organization, the organization is promulgating regulations for the behavior of (at least) its own members (and, typically, other social actors as well), and the organization has a distinctive collection of cultural practices and symbols. Whenever one of these measures changes, when inclusion goes up or down, when regulation goes up or down, or when distinctiveness goes up or down, social conflict typically follows.

Organizational space is always changing, sometimes quickly, sometimes slowly, hence the existence of organizational time. People leave one employer for another. A computer firm buys a competitor. A government agency claims control over the serious hazard of "second-hand smoke." A company starts requiring its employees to come to work instead of telecommuting. An airline begins service to a new city.

\section{ORGANIZATIONS HAVE BOUNDARIES, REGULATIONS, AND}

\section{DISTINCTIVENESS}

Organization is the corporate dimension of social life. Especially in modern times, formal organizations pervade society (Lune 2010, p. 1). Formal organizations provide much of goods and services used by the population. Formal organizations also regulate large parts of social life. Most modern people spend their working 
lives in a series of formally organized settings called corporations, firms, agencies, partnerships, non-governmental organizations, etc.

There are literally hundreds of measures of organizations (Price and Mueller 1986). But many of these measures can be seen as aspects of three fundamental things: first, the line between the organization and its environment; second, the rules that the organization promulgates; and third, the subculture that gives the organization its distinct identity in the larger social world. Thus, for our purposes, organizations have three distinct attributes. The first is the boundary line between the organization and the rest of the social world. Everything is on one side of the boundary or the other. Organizational boundaries are manifold, covering everything from people, property, land, money, etc. All of these things can belong to an organization. When people or sub-organizations are inside the boundary, then to be inside is to be included. We shall extend the idea to cover all of the organization's contents. Most organizational boundaries are fairly distinct. People either work for the Hankyu Railway or they don't. Criminals are either "made men" or they're not. A parcel of land either belongs to the Catholic Church or it doesn't. Practically anything in society can move across an organizational boundary. And when it does, conflict often ensues. 
The second crucial feature of organizations is their regulation of human activities. Organizations are behavior-regulating entities. They command and control the behavior of members and, often, non-members. Over how much do they hold sway? Does a government claim to control every aspects of people's lives, as in North Korea today, or is it more of a minimalist regime, like that of Hong Kong? Does a corporation set prices as part of an effective oligopoly or is it at the mercy of turbulent markets? Does an employer tell employees that they cannot smoke, even in their own homes, or does it ignore all health-related behaviors? An organization's regulation of behavior can increase or decrease. When it does either one, social conflict typically occurs.

The third important feature of organizations is their identity as expressed by their subcultures. Organizations contain - and are largely defined by - a unique collection of expressive elements. Organizations often have their own clothing, flags, vocabularies, publications, manners, and even foods. As in the larger social world, diversity in the organization's subculture can vary. When it does, this can cause conflict.

\section{OVERORGANIZATION AND UNDERORGANIZATION}

Overorganization is an increase in the organization's extent, either in terms of what is inside the organization (overinclusion), in the control of behavior 
(overregulation), or an increase in the organization's cultural distinctiveness (overdistinction). If the organization grows in size, begins to exercise new powers, or becomes more culturally distinct, overorganization has occurred. Conversely, underorganization is the shrinking of the organization in size, authority, or distinctiveness. In the extreme form of underorganization, the organization disappears. If the organization shrinks, that is, if something that is inside the organization moves outside of it or disappears, underinclusion has taken place. If the organization abandons its claims of authority or adopts a laissez-faire attitude, underregulation has occurred. If an organization loses some of its subcultural distinctiveness, underdistinction has occurred.

\section{Overinclusion}

Overinclusion is crossing the organizational boundary in an inward direction. Organizations can grow in vast number of dimensions. The organization can induct new members, conquer territory (either on the battlefield or in regional sales), increase revenues, buy up patents, merge with a competitor or a supplier, or build itself a new headquarters.

Conflict is a direct function of overinclusion. 
Few large organizations are ever built except through protracted social conflict. The birth and childhood of labor unions in the U.S. was a century-long bloodbath of strikers and scabs, boycotts and sit-ins, arrests and trials, bombings and massacres (Dray 2010). On the other side of the economy from the workers, corporate mergers and acquisitions have their own turbulent history of social conflict (Perrow 2002; Useem 1996). A rich vocabulary describes the complicated sets of players and their ruthless behaviors. "Corporate raiders" threaten to seize control of boards of directors and fire existing management. "White knights" are potential merger partners who will not destroy existing management. "Bankmail" is the practice of getting a bank to promise not to finance any other raider's takeover bid. Corporations that feel they might be the target of a hostile takeover may take a "poison pill," which typically gives all shareholders other than the raider the opportunity to buy more shares at a discount, thus making the takeover more expensive and difficult.

Even mostly organic, internal business growth causes conflict (Morrill 1995). IBM and Microsoft were both sued in their time by the Federal Government for their allegedly monopolistic practices. Today, Apple, Google, and Amazon sue each other and are in turn threatened with legal action by various government agencies, both in the United States and abroad. 
Many instances of the movement of organizational time are resisted and this resistance is more successful when the organization itself is stronger. When the Department of Homeland Security was created, relatively weak organizations such as the U.S. Coast Guard could not resist the pull. But the Federal Bureau of Investigation, one of the most prestigious agencies in the Federal Government, successfully thwarted efforts to move it from the Department of Justice to the new Department of Homeland Security (Mueller 2002).

When Texas A and I University in Kingsville, TX was merged into the Texas A and M System in 1989, many alumni of "A and I" objected. Later they were outraged over changes in "their" organization, including its name (in 1993). The conflict simmers today (Texas A and I Alumni Association 2014). (The school was originally called "South Texas State Teachers College," then "Texas College of Arts and Industries" in 1929, and became "Texas A and I University" in 1967.)

A standard model of stages of organizational growth and change famously labels the "crises" that an expanding organization must undergo and resolve (Greiner 1972; Hatch and Cunliffe 2012, p. 106). From a small start-up, the organization grows through the "leadership crisis, the "autonomy crisis," the "control crisis," the "red-tape crisis," and the "renewal crisis." These "crises" are themselves social conflicts. Successful resolution of each crisis with a new management 
structure (entrepreneurial, directed, delegated, formalized, and collaborative) allows continued growth.

Joining organizations is often a fraught process. Other social actors may resent the new claims on the person's time, loyalty, and identity. When "greedy institutions" like the military impose regulations on their members, the impact is felt as conflict with other roles, especially family roles (Segal 1986). Rituals of passage, such as military induction ceremonies, stress the abandonment of previous roles and the importance of commitment to organizational norms and purposes.

\section{Overregulation}

Overregulation is an increase in an organization's regulation of someone's behavior, whether inside or outside the organizational boundary. Change in the regulation of behavior is often expressed by expanding the rules of the organization, their breadth, detail, formality, force, and so on. A company decides to tell its employees to lose weight or to stop smoking. The US Federal Government demands that all employers in the country fill out a form (the I-9) for every employee (proving that the employee has the right to work in the United States) and put the form in a file somewhere forever. (The I-9 form is not sent anywhere, it is merely archived by the employer forever as a talisman of compliance.) 
Organizational time also includes change in internal organizational practices such as formalization. An increase in formalization is a movement of organizational time and may cause conflict, as famously lampooned in the "TPS reports" of the film Office Space (2002).

\section{Conflict is a direct function of overregulation.}

When an organization increases its command and control over activities inside and outside its boundaries, conflict often ensues. From 2001-2009, Richard Cheney re-defined the office of the Vice-President of the United States to give it dramatically increased authority within the Executive Branch and vis-à-vis other parts of the government. This created enormous conflict within the Federal Government: in one famous episode, one of the Vice-President's subordinates yelled at other government officials: "You are out of your lane." (Gellman 2009). The Office of Civil Rights of the U.S. Department of Education is presently engaged in efforts to regulate sexual behavior on American college campuses by extending the definitions in its mandate to ensure equal opportunity to educational programs that receive federal funding (Wilson 2014). These efforts are being questioned and resisted by various other actors. This extension of regulation is 
patterned on the earlier definition of sexual harassment as employment discrimination (Dobbin 2009).

Whatever else Western colonialism was, it was often the imposition of a more organized way of life on peoples typically lacking much formal organization. And this was actively resisted in conflicts that set the pattern of much of world history for several centuries.

Even the anticipation of overregulation may cause social conflict. In the post-9/11 world, the U.S. (and other) governments have increased their domestic and foreign surveillance efforts. Surveillance is an initial part of the apparatus of organizational regulation: to respond to deviance, the organization must first learn about it. But this is being resisted. In 2013, a small town in Colorado considered issuing "drone-hunting" permits that supposedly would allow the bearer to attack unmanned aircraft sent on surveillance missions that seemed like overregulation to the residents. Apple Computer has announced that it will equip some of its services with encryption that Apple itself cannot open so that Apple can no longer comply with subpoenas for its customers' data (Apple 2014).

\section{Overdistinctiveness}


Overdistinctiveness is an increase in the organization's distinctive subculture. A coffee shop starts referring to its small cup size as "tall", its medium cup size as "grande", and its large cup as "venti”. Organizational managers are routinely instructed to increase organizational performance by manipulating the local culture with distinctive clothing, vocabulary, rituals, signs, etc. This tactic was also lampooned in Office Space (1999) when Jennifer Aniston's character is therapeutically berated by her boss for her minimalist approach to her "pieces of flair”. She responds by yelling and quitting.

\section{Conflict is a direct function of overdistinctiveness.}

In many instances of increasing expressive distinctiveness, social conflict follows directly. In 2005, the National Basketball Association sought to position its sport higher in the American media universe by requiring players and coaches to wear "business attire" at games, interviews, charity events, etc. Brawls and a perceived association with urban minority youth culture led the NBA to attempt to make itself distinctively wholesome among U.S. spectator sports. Not all players were delighted with the move and some complained that they were not being allowed to "express themselves" (Wise 2005).

\section{Underinclusion}


Underinclusion is crossing the organizational boundary in the outbound direction. Deserters leave their armies. Individual workers quit their jobs. Masses of workers go on strike. States secede from the Union. The U.S. Army Air Corps demands to become the U.S. Air Force. Sometimes everything in the organization crosses the boundary and the organization evaporates into thin air, like the Civil Aeronautics Board at the end of 1984 . When a political organization such as the USSR disintegrates - a gigantic movement of organizational time - wars erupt (Collins 1986). National governments come into being though social conflict and are amalgamated or destroyed by social conflict. International wars can be understood as attempts to highlight, move, or erase boundaries between governments, that is, locally supreme political organizations (Caplow and Hicks 2002). And the conflict of leaving leads to more conflict later on: as Vladimir Putin's government has made efforts toward re-unifying pieces of the old Soviet empire, conflict has erupted.

\section{Conflict is a direct function of underinclusion.}

When individuals leave organizations, there is often conflict. Deserters are often killed --- the Wehrmacht executed thousands of its own soldiers as the Red Army bore down on the German Fatherland (Bartov 1991). Indians captured during the "Great Mutiny" were "shot from cannon" (Herbert 2007). Initiates who are 
deemed to have failed to meet an organization's standards become non-persons. Assistant professors who have been denied tenure seemingly cease to exist for the entire academic year afterward while they continue to teach in the department and look for another job.

Special instances of secret underinclusion are called shirkers, leakers, spies, and traitors. Unlike the deserter, these secret perpetrators of underinclusion remain inside the organizational boundary. But other things are sent across the boundary: information, effort, and loyalty. The ensuing social conflict can be epic: evisceration and incineration. Treason is the only crime explicitly defined in the United States Constitution (Article 3, Section 3). A common expression in the U.S. military for a soldier with a long history of shirking is "ROAD", meaning "Retired On Active Duty." Here is an explicit use of the organization's boundary to label the deviant behavior of a member of the organization who is not actually outside the boundary (yet).

\section{Underregulation}

Underregulation is a decline in the organization's regulation of someone's behavior, either inside or outside of the organizational boundary. Organizations often abandon regulatory efforts for a host of reasons: ideology, expense, impracticality, etc. The general fear of conflict as a result of declining authority is 
a consistent theme of political thought. In Plato's Republic (2008), this fear is an attribute of civilization: "The obligation of maintaining authority under all circumstances and sometimes by rather questionable means is felt strongly and has become a sort of instinct among civilized men."

\section{Conflict is a direct function of underregulation.}

A sudden reduction in regulation creates chaotic conflict. The U.S. viceroy in occupied Iraq, Ambassador Paul Bremer told the Iraqis that their economy was now free. Their businesses had been unshackled from the stultifying hand of government. Iraqi businessmen were horrified. Without the Iraqi state to set limits on business behavior, the Iraqis expected deadly chaos. And they were right (Klein 2008, p. 433; Chandrasekaran 2007).

Business students are taught that as managers they should seek to stimulate conflict among subordinates by withholding guidance (an example of underregulation). This stimulation of conflict is intended to increase productivity or creativity by stimulating activity generally (Hall 2001).

When a prison riot succeeds in overthrowing the guards' authority, at least locally and temporarily, watch out. There typically follows an orgy of score-settling 
violence among the inmates, along with any captured guards (Morris 1988). This conflict arising from underregulation is typically followed by conflict from overregulation as the guards re-take the facility, often in another orgy of brutal violence (Wicker 2011).

\section{Underdistinctiveness}

Underdistinctiveness is a decline in the cultural distinctiveness of the organization. The organization may abandon some of its special vocabulary. It might stop wearing uniforms and adopt normal street clothing. The organization could cease holding distinctive rituals and try to quietly let their memory fade away. It could start recruiting members that more closely approximate its surroundings in terms of gender, education level, race, ethnicity, religion, or any other relevant social distinction.

\section{Conflict is a direct function of underdistinctiveness.}

When the Catholic Church moved away from the Latin Mass after Vatican II and began performing the ceremony in the local languages - a massive decline in cultural distinctiveness - enormous conflict erupted (Greeley 2004). Elite investment banks are deeply reluctant to dilute their internal distinctiveness by hiring new employees who come from different social backgrounds. Even in the 
face of external pressure, many firms are reluctant to embrace programs aimed at workplace diversity (Dobbin, Kim, and Kalev 2011).

Sometimes the movement of social time is inside a large organization. For example, the U. S. Army is composed of hundreds of differently named and numbered units, many with their own zealously guarded identities. From 1979 onward, a single elite infantry unit of the U.S. Army called the $75^{\text {th }}$ Ranger Regiment had been allowed to wear a black beret in place of the usual fatigue cap worn by most other American soldiers. In 2001, the Chief of Staff of the Army decided that morale of all soldiers could be improved by issued the black beret to the entire Army. The Rangers were outraged and demanded that the decision be rescinded. The controversy became public and reached the White House. The President of the United States of America asked the Secretary of Defense to consider the matter. Members of Congress threatened to summon the Chief of Staff of the U.S. Army to testify about why money was being spent to dilute the distinctiveness of the Ranger Regiment. After due deliberation, the decision stood. However, to maintain the distinctiveness of the Rangers, they were issued tan berets, again wearing a different hat than all other soldiers (Department of Defense 2001).

CONCLUSION 
The fundamental dimensions of social space described in Donald Black's Moral Time have analogues in the world of formal organizations. The relational dimension appears as inclusion in the organization. The vertical dimension appears as regulation by the organization. The cultural dimension appears as the cultural distinctiveness of the organization. Changes in organizations are movements along these dimensions. Such changes often cause social conflicts.

The social conflicts that arise from movements of organizational space are often momentous and consequential. Movements across organizational boundaries, changes in organizational regulation, and changes in organizational distinctiveness are the origin of much of the conflict that can be seen across the social world. Thinking of social conflicts as arising from organizational time allows explanations of the conflicts of economic deregulation, corporate raiding, and political disintegration that are as simple and elegant as Black's explanations of the conflicts of adultery, artistic innovation, and witchcraft. 


\section{REFERENCES}

Apple Corp. 2014. "Privacy.” http://www.apple.com/privacy/privacy-built-in/ Accessed November 18, 2014.

Bartov, Omer. 1991. Hitler's Army; Soldiers, Nazis, and War in the Third Reich. Oxford: Oxford University Press.

Baumgartner, M.P. 1991. The Moral Order of a Suburb. New York: Oxford University Press.

Black, Donald. [1976] 2010. The Behavior of Law. Special edition. Bingley: Emerald Group.

Black, Donald. 1998. The Social Structure of Right and Wrong. San Diego: Academic Press.

Black, Donald. 2011. Moral Time. New York: Oxford University Press.

Campbell, Bradley. 2009. "Genocide as Social Control." Sociological Theory 27:150-172. 
Caplow, Theodore and Louis Hicks. 2002. Systems of War and Peace. $2^{\text {nd }}$ ed. Lanham, MD: University Press of America.

Chandraskaran, Rajiv. 2007. Imperial Life in the Emerald City. New York: Vintage.

Collins, Randall. 1986. “The Future Decline of the Russian Empire.” Pages 186209 in Weberian Sociological Theory. Cambridge: Cambridge University Press.

Cooney, Mark. 2009. Is Killing Wrong? A Study in Pure Sociology.

Charlottesville: University of Virginia Press.

Department of Defense. 2001. “Defense Leaders Uphold Army's Black Beret Decision (Corrected Copy)." Press release. DOD at http://www.defense.gov/news/newsarticle.aspx?id=45776, accessed November 18, 2014.

Dobbin, Frank. 2009. Inventing Equal Opportunity. Princeton: Princeton University Press. 
Dobbin, Frank, Kim Soohan and Alexandra Kalev. 2011. "You Can’t Always Get What You Need: Organizational Determinants of Diversity Programs." American Sociological Review 76:386-411.

Dray, Phillip. 2010. There is Power in a Union: The Epic Struggle of Labor in America. New York: Doubleday.

Gellman, Barton. 2008. Angler: The Cheney Vice-Presidency. New York: Penguin.

Greeley, Andrew. 2004. The Catholic Revolution: New Wine, Old Wineskins, and the Second Vatican Council. Berkeley: University of California Press.

Greiner, Larry. 1972. "Evolution and Revolution as Organizations Grow." Harvard Business Review 50(4):37-46.

Hall, Richard H. 2001. Organizations: Structures, Processes, and Outcomes. $8^{\text {th }}$ ed. Upper Saddle River, NJ: Prentice-Hall.

Hatch, Mary Jo and Ann L. Cunliffe. 2012. Organization Theory: Modern, Symbolic, and Postmodern Perspectives. Oxford: Oxford University Press. 
Herbert, Christopher. 2007. War of No Pity: The Indian Mutiny and Victorian

Trauma. Princeton: Princeton University Press.

Klein, Naomi. 2008. The Shock Doctrine; The Rise of Disaster Capitalism. New York: Picador.

Lune, Howard. 2010. Understanding Organizations. Cambridge: Polity Press.

Manning, Jason. 2012. “Suicide as Social Control.” Sociological Forum 27(1):207-227.

Michalski, Joseph H. 2003. "Financial Altruism or Unilateral Resource Exchanges? Toward a Pure Sociology of Welfare." Sociological Theory 21:341358.

Morrill, Calvin. 1995. The Executive Way; Conflict Management in Corporations. Chicago: University of Chicago Press.

Morris, Roger. 1988. The Devil's Butcher Shop: The New Mexico Prison Uprising. Albuquerque: University of New Mexico Press. 
Mueller, Robert. 2002. FBI Director's Testimony before the U.S. Senate Committee on Governmental Affairs, June 27, 2002.

Office Space. 1999. Directed by Mike Judge. Produced by $20^{\text {th }}$ Century Fox.

Perrow, Charles. 2002. Organizing America: Wealth, Power, and the Origins of Corporate Capitalism. Princeton: Princeton University Press.

Plato. 2008. The Republic. Trans. By Benjamin Jowett. Project Gutenberg at http://www.gutenberg.org/files/1497/1497-h/1497-h.htm, accessed November 18, 2014.

Price, James L. and Charles W. Mueller. 1986. Handbook of Organizational Measurement. Marshfield, MA: Pitman.

Texas A and I Alumni Association. 2014. Open Letter.

http://www.texasaandiuniversity.com/openletter.aspx, accessed November 18, 2014. 
Segal, Mady. 1986. "The Military and the Family as Greedy Institutions." Armed Forces and Society 13(1):9-38.

Useem, Michael. 1996. Investor Capitalism: How Money Managers are Changing the Face of Corporate America. New York: Basic Books.

Wicker, Tom. 2011. A Time to Die: The Attica Prison Revolt. Chicago: Haymarket Books.

Wilson, Robin. 2014. "Why Colleges Are on the Hook for Sexual Assault." Chronicle of Higher Education, June 6, 2014.

Wise, Mike. 2005. "Opinions on the NBA's Dress Code are Far from Uniform." Washington Post, October 23, 2005. http://www.washingtonpost.com/wpdyn/content/article/2005/10/22/AR2005102201386.html accessed on November $18,2014$. 